\title{
Is sustainable logging possible in Africa's dense forest?
}

\author{
Alain KARSENTY ${ }^{1,2}$ \\ ${ }^{1}$ CIRAD \\ UPR GREEN \\ Campus international de Baillarguet \\ 34398 Montpellier Cedex 5 \\ France \\ 2 GREEN, Univ Montpellier, CIRAD \\ Montpellier \\ France
}

Auteur correspondant / Corresponding author:

Alain Karsenty - alain.karsenty@cirad.fr

This was the question raised in the early 1960 s by René Catinot, a former research director with the French Tropical Forestry Centre, CTFT ${ }^{1}$, which would later become the Forestry Department of the CIRAD, and a historic figure in French tropical forestry. As Catinot describes, as soon as they arrived in tropical Africa, "the forestry engineers responsible for managing its dense forests embarked on efforts to regenerate them" . Knowledge on forestry in temperate regions was inadequate to the task of managing forests harbouring some 200 to 300 species but containing far less timber than any managed forests in temperate zones. A debate then arose over the merits of natural versus artificial regeneration. The problem with selective logging in tropical forests, especially in Africa, is that because the percentage of trees felled is very low, not enough light reaches the ground to encourage germination of the most commercially valuable species, which often tend to be light-loving. Catinot states categorically that it is not possible to "count on Nature alone to ensure their regenera-

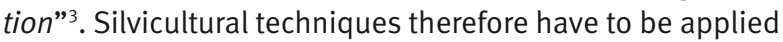
to promote the development of these commercial species, either by "encouraging seeding and growth of pre-existing species" (silviculture based on natural regeneration) or by "transplanting noble species produced in tree nurseries into forests that have been exhausted by logging" (artificial regeneration): the word "noble" clearly reflects the

Centre Technique Forestier Tropical. The C.T.F.T. was incorporated into the CIRAD as a forestry department in 1984. 2 In p. 9 of the article: Catinot R., Bossanyi I., 2018. Silviculture in African dense forest. Bois et Forêts des tropiques, 336: 7-18. 3 Ibidem. conceptions of the time. The idea of "biological diversity" did not emerge until 1968 and it took several more years to understand that "biodiversity" does not mean just the sum of species, but all interactions between living organisms. What is Catinot, who clearly expressed the thinking of tropical foresters at the time, actually saying? Silviculture based on natural regeneration "is basically a slow and cautious destruction of the canopy" by removing lianas, clearing the undergrowth and poisoning "unwanted species". As for artificial regeneration, "again, the pre-existing forest has to be destroyed to give the new seedlings enough light for them to grow" 4 . This kind of language would be totally unacceptable today, when "low-impact logging" is the order of the day and the FSC (Forest Stewardship Council) programme of certification of "sound forest management" is questioning whether even low-impact logging is compatible with maintaining "intact forest landscapes".

While attitudes towards species diversity have changed profoundly, the problems raised by René Catinot have remained strikingly relevant, especially when we look at the difficulties encountered by large logging companies in central Africa as a result of the increasing scarcity of the main commercial species in timber forests. Catinot tells us that the French foresters who arrived in Côte d'Ivoire from 1924 to 1930 first attempted and then abandoned natural regeneration, believing "that the local natural and economic conditions were totally unsuitable: because there was no local timber market, only a few 'noble species', none of them common in the forest, were felled for export, which resulted in a kind of selection in reverse by removing the seed trees of species of interest and leaving all others standing, while felling only about 3 trees per hectare could not open the canopy

${ }^{4}$ Idem, p. 10.

Doi : $10.19182 / \mathrm{bft} 2018.336 . \mathrm{a} 31615$

Droit d'auteur (c) 2018, Bois et Forêts des Tropiques (c) Cirad

Date de soumission : 13 mars 2018 ; date d'acceptation : 13 mars 2018 ; date de publication : $1^{\text {er }}$ avril 2018

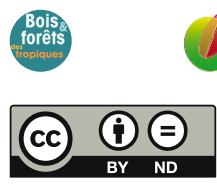

\section{cirad}

icence Creative Commons

Attribution - Pas de Modification 4.0 International.

Attribution-NoDerivatives 4.0 International (CC BY-ND 4.0)

Citer l'article / To cite the article

Karsenty A., 2018. Is sustainable logging possible in Africa's dense forest? Bois et Forêts des Tropiques, 336: 3-5. Doi : $\underline{10.19182 / b f t 2018.336 . a 31615}$ 
Bois et Forêts des Tropiques - ISSN: L-0006-579X

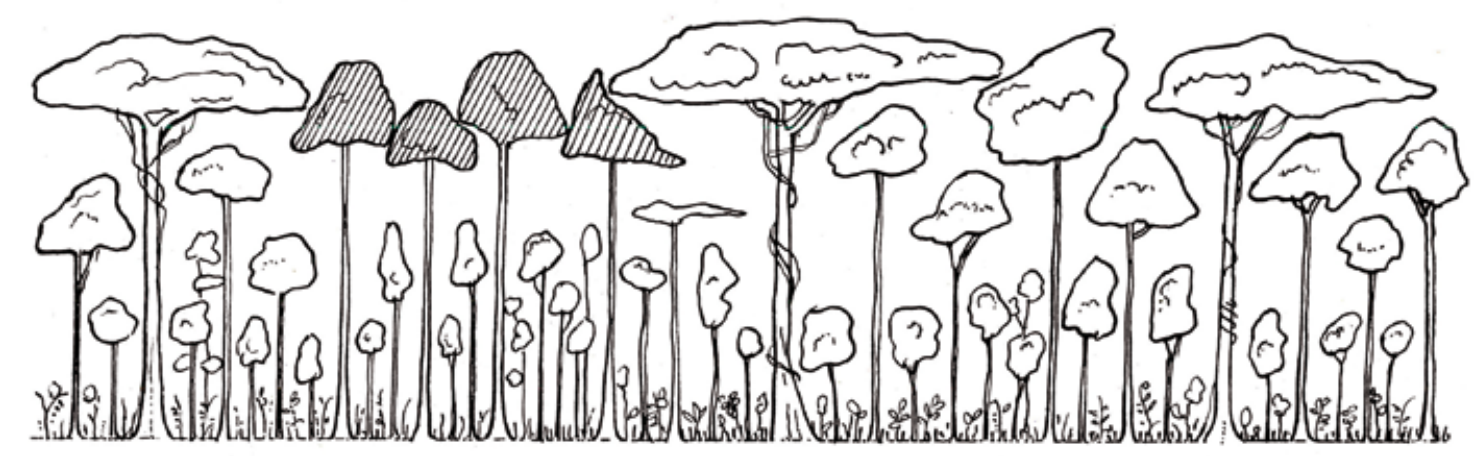

Before improvement work

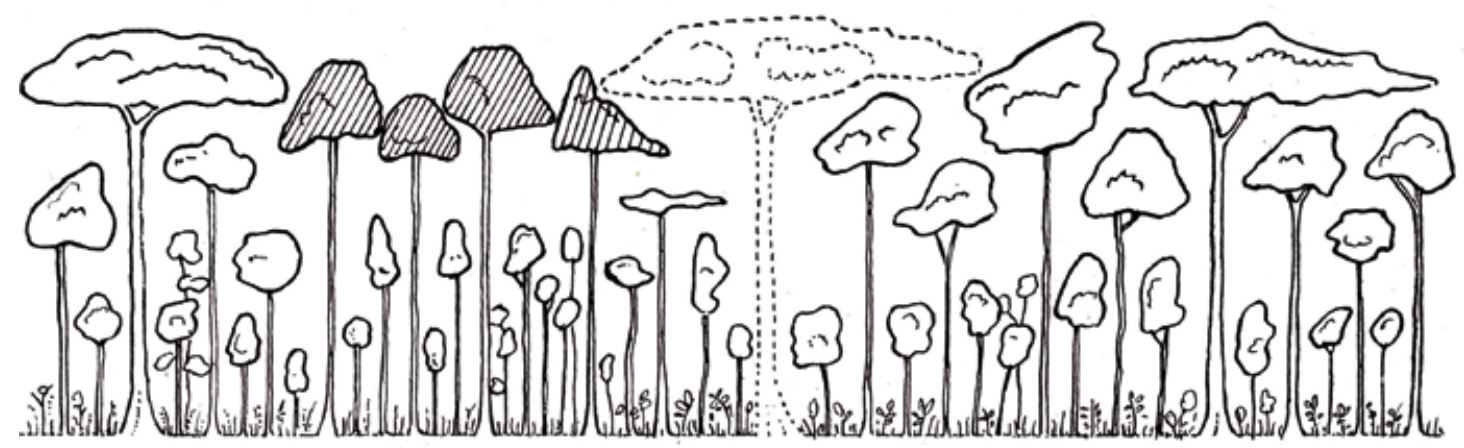

After improvement work

Diagram showing improvement work in a stand of Okoumé (hatched) $(20<\varnothing<40 \mathrm{~cm})$ : suppressing unwanted trees by girdling (dotted lines). Figure extracted from the article (p. 13): Catinot R., Bossanyi I., 2018. Silviculture in African dense forest. Bois et Forêts des tropiques, 336: 7-18.

enough to warrant regeneration cutting" 5 . This description still applies very much to Africa today, the main difference being that a local market does exist, but is supplied by small-scale loggers who are looking for the same "noble species" as industrial-scale loggers but, because they work in the "informal" sector, can offer their timber at prices that poor consumers can afford. As artificial regeneration in natural forests is very costly, because of the vast areas covered by forestry concessions, the forest management plans adopted from the 1990s were based on natural regeneration techniques seeking to minimise damage to what forest remained. But the outcome was exactly what Catinot warned against: the canopy remained too dense for enough light to reach the ground to regenerate commercial sun-loving species, while the most commercially valuable species became depleted because the best seed trees were being removed.

With most of West Africa's great forests now lost, the current crisis among some large European logging companies in Central Africa is revealing a situation that is throwing doubt over the very possibility of sustainable logging based on forestry techniques involving natural regeneration ${ }^{6}$. In early 2018, the African branch of the Rougier Group announced that it was going into liquidation. Looking

${ }^{5}$ Idem, p. 11.

${ }^{6}$ For further details on this situation, see: Karsenty A., 2018. La crise de la filière européenne du bois tropical en Afrique centrale. Wilagri, 9 p. www.willagri.com/2018/06/28/la-crise-de-la-filiereeuropeenne-du-bois-tropical-en-afrique-centrale/ beyond various short-term contingencies (saturation of the port of Douala, delays in VAT reimbursements owed to exporters, etc.), there is a sense among timber companies of nearing the end of a relatively virtuous economic cycle, which began with the forest management plans of the 1990s and continued with the boom in FSC certification for "sound forest management" some fifteen years later. It was thought at the time that sustainable logging in natural forests, aiming to cater at once for profitability, ecological compatibility and social progress, had been demonstrated as feasible in central Africa, despite the notorious governance problems in that region.

Meanwhile, profits from logging in natural forests have continued to rely on a handful of species that are familiar to consumers: Okoumé (Aucoumea klaineana) in Gabon, Ayous (Triplochiton scleroxylon), Sapelli (Entandrophragma cylindricum) and Azobé (Lophira alata) in Cameroon, Sapelli in northern Congo-Brazzaville and Okoumé in the south and Sapelli in the Central African Republic, while in the DRC, profits can still be made from a few valuable species like Wengé (Millettia laurentii) and Afrormosia (Pericopsis elata). But concentrating the timber harvest on this handful of species is gradually depleting "deposits" as more forest areas are systematically turned over to logging. In theory, this depletion does not mean that the species in question are facing extinction. The problem is economic: the timber volumes that remain after the second logging cut (legally, 25 to 30 years after the first) are not usually sufficient to 
sustain industrial-scale logging to meet market demand. The example of Rougier is a case in point: the company's purchase, en 2015, of a logging concession in the Central African Republic was supposed to secure supplies for the group's main processing plant in Cameroon, which was relatively close to the border with the Central African Republic. This was a direct consequence of the decline in available volumes of Sapelli and Ayous in eastern Cameroon, which had been repeatedly logged over, by industrial companies but also small-scale loggers, for several decades. In Cameroon, Wijma's abandon of several concessions was also linked to the steep decline in Azobé volumes after the first logging cut in these concessions.

Although there are still many Sapelli trees in the northern Congo concessions and Okoumé trees in Gabon, loggers are sensing that the end of a cycle is closing in, and that the "primary forest dividend" - the exceptional timber volumes obtained from the first logging cuts in old-growth forests - is gradually wearing thin. Of course many other species are, or could be, logged in these forests. But, either they are not abundant enough to replace the traditional commercial species, or their sale price is not high enough compared to the costs of logging operations, transport and, in some cases, processing.

Plantations of timber species would be a logical solution to the exhaustion of traditional "deposits" in natural forests. But it is well known that without powerful economic incentives or directives imposed by clear-sighted governments, companies will not invest in costly plantations that cannot produce timber returns for three decades. Furthermore, silvicultural techniques for the most economically attractive species are not always properly applied, and quality can be lacking: planted okoumé trees, for example, do not produce timber of the same quality as okoumé trees growing in the wild. Finally, there is the question of property rights: in thirty years time, who would own the rights to trees planted in timber concessions by companies that may, by then, have ceased trading?

Does this mean that René Catinot's prediction precludes any prospect of sustainable logging based on natural regeneration methods, and that the costs (and ownership issues) inherent to plantations of slow-growing timber species bar any forestry techniques from generating value from the diversity of tree species in Africa's forests?

These are disturbing questions, to which we will attempt to bring some less pessimistic answers.

The "historic" operators are now also paying the price of inadequate investments in technical innovation and marketing. Contrary to a common assumption, most African timber exported today is locally processed. While some timber companies, Italian in particular, have gained a competitive edge by offering sophisticated and attractive products, most timber processors have kept the same focus on "commodities", meaning standard-sized saw-wood, peeled veneer wood and plywood. Trading in commodities means trading as "price-takers", who will always be directly dependent on world market prices and the changing preferences of consumers - who easily turn to Asian or even temperate and northern timber whenever African timber prices rise above their comfort zone.

Manufacturing finished products, devising intelligent uses for timber by-products, finding appropriate uses for abundant but low-value species (for example as core plywood layers, as Asian industries are doing by inserting poplar between layers of "noble" wood) are all possible ways of retrieving the added value that is gradually being lost with the decline of the traditional species on which the boom in Africa's timber industry was built. Optimising the value chain can also mean making use of waste wood as fuel for CHP plants, whenever the context is suitable and monthly wood production high enough for this to be profitable. Although the difficulties facing such projects in countries plagued by inadequate infrastructure, a cruel lack of skilled personnel and exorbitant over-costs must not be underestimated, the fact remains that some European companies now in difficulties probably did not invest the healthy profits they harvested in more auspicious times as wisely as they might have. It is also the case that not all European timber companies in central Africa have been affected by difficulties on the scale of those experienced by the Rougier Group. Several companies in Gabon, Cameroon and Congo-Brazzaville, all with FSC certification, seem to be faring well in equally fraught economic and political contexts.

The solution also lies partly in the hands of the states concerned. Improving infrastructure, reducing administrative red tape and para-taxation means reducing costs and therefore increasing the value of their standing timber and making it possible to turn profits from the use of certain less commercially valuable species that are currently left standing. The question of property rights is still a major problem where tree plantations are concerned, whether in forests (enrichment) or elsewhere. The legislation is gradually evolving, as in Côte d'Ivoire, towards the abandon of systematic state ownership of all trees in natural forests. But the rights of the different players still need to be made secure, even (and especially) if they use the same lands. Sustainability also depends on governance.

Bois et Forêts des Tropiques - Revue scientifique du Cirad

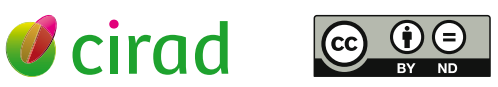

(c) Bois et Forêts des Tropiques (c) Cirad - Campus international de Baillarguet, 34398 Montpellier Cedex 5, France Contact : bft@cirad.fr - ISSN : L-0006-579X 